\title{
How Important was the Presence of Elephants as a Determin: Zhizo Settlement of the Greater Mapungubwe Landsca]
}

\author{
Tim Forssman*, Bruce Page \& Jeanetta Selier
}

Résumé

\begin{abstract}
The initial settlement of the Greater Mapungubwe Landscape by Zhizo ceramic-producing farmers around AD 900 is said to be linked to the large elephant population that the region once supported. Elephant ivory was used in the Indian Ocean trade network to obtain exotic trade goods such as glass beads and cloth. However, there has been no attempt to determine whether the local elephant population was large enough to support such trade endeavours. In this paper, we use an inter-disciplinary approach to establish a projection of the past elephant population and demonstrate that the ivory tonnage in the region, including that which could be recovered from natural carcasses, could have supported trade demand. We also argue that at the time of settlement the same environmental productivity supporting the elephant population provided an ecological system amenable to cultivation and could support domesticated livestock. In addition, the local topography, river networks and community of large mammalian herbivores contributed to the attractiveness of the region from a settlement perspective. We believe that the elephant population was only one component present on the landscape that attracted agriculturalists to settle in the area.
\end{abstract}

L'occupation initiale du Greater Mapungubwe Landscape par des fermiers Zhizo producteurs de céramiques autour 900 ap. J.-C. est supposément liée à la grande population d'éléphants que la région aurait alors accueillie. L'ivoire d'éléphant était utilisé dans un réseau d'échanges avec l'Océan Indien pour obtenir des marchandises exotiques comme des perles de verre et du tissu. Cependant, il n'y a eu aucune tentative pour déterminer si la population d'éléphants locale était assez importante pour soutenir de tels efforts commerciaux. Dans cet article, nous utilisons une approche interdisciplinaire pour obtenir une projection de la population d'éléphants de cette époque et démontrer que le tonnage d'ivoire dans la région, y compris celui qui pouvait être récupéré sur des carcasses naturelles, a pu être suffisant pour répondre à la demande commerciale. Nous soutenons aussi qu'au moment de l'occupation, l'environnement qui permettait la présence des éléphants, a également fourni un système écologique favorable à l'agriculture et à l'élevage. En outre, la topographie locale, les réseaux hydrographiques et la population de grands mammifères herbivores contribuaient à rendre la région attractive dans la perspective d'un établissement. Nous croyons que la population d'éléphants était seulement une composante de ce paysage qui a incité les agriculteurs à s'installer dans la région.

Keywords: Zhizo, Greater Mapungubwe Landscape, Indian Ocean trade network, elephants

Tim Forssman * tim.forssman@up.ac.za (correspondence author)

Anthropology and Archaeology Department, University of Pretoria, South Africa

Bruce Page

School of Life Sciences, University of KwaZulu-Natal, South Africa

\section{Jeanetta Selier}

School of Life Sciences, University of KwaZulu-Natal, South Africa and South African National Biodiversity Institute, Pretoria, South Africa 


\section{Introduction}

The Greater Mapungubwe Landscape, which includes northern South Africa, northeastern Botswana and southwestern Zimbabwe (Fig. 1), is ecologically unique in the southern African environment, and distinctively suitable for human settlement (see HuFFMAN 2000; SMITH 2005). Several ecological factors combine to promote unusually high concentrations of both primary productivity and nutritional quality of vegetation in a relatively small area that in turn gives rise to high secondary productivity (e.g., Smith 2005; Manyanga 2006; Huffman 2008). The primary factors responsible are the optimal temperatures, rainfall, the nutritional and moisture status of the soils - all of which arise because of the number of large rivers that drain into the Limpopo River over a short distance - the relatively flat terrain which promotes extensive flooding, the deposition of clays and the creation of extensive alluvial deposits (see DENBOW 1984; ManYanga 2006). According to Smith (2005), low annual rainfall would not have limited the cultivation of domestic crops because tributaries and wet areas in the sandstone zone could provide sufficient moisture. According to SELIER (2007), these ecological resources, in addition, supported a large wildlife population, especially of African elephant (Loxodonta africana).

The occurrence of elephant remains in archaeological contexts, whether from hunting exercises or scavenging, extends back at least 30,000 years in southern Africa (Plug \& BADENhorst 2001: 20). On the Greater Mapungubwe Landscape the role of elephants in early agriculturalist society has been afforded great distinction because of their suggested link to international trade. The region was occupied by foragers from about 12,000 BP (VAN DOORNUM 2008), and only by agriculturalists from the beginning of the first millennium AD (HuFFman 2000). At first the agriculturist occupation was probably represented by a low population density (HALl \& SMith 2000), but by AD 900, Zhizo ceramicproducing agriculturalists had firmly established themselves in the region (HuFFMAN 2000). HuFFMAN (2000) suggests that their local settlement was undertaken in order to exploit the large elephant herds that lived in the basin, specifically around the vlei (wetland) areas and along tributaries (e.g., DE BEER \& VAN AARDE 2008), for the purpose of obtaining their ivory and using it as a trade good. It was apparently this reason that prompted the local occupation of the Greater Mapungubwe Landscape, a point that we contest here.

In this paper, we test two hypotheses. Firstly, the local elephant population was large enough to support trade with the east coast of Africa and secondly, the local environment was a favourable landscape upon which to settle from an agricultural perspective. Our goal is to contribute to discussions on the initial settlement of the Greater Mapungubwe Landscape by Zhizo ceramic-producing agriculturalists and possibly suggest an alternative approach to understanding this critical point in the area's archaeological sequence, which began the processes of state development (see HuFFMAN 2000). By doing so, we demonstrate the general lack of understanding for this period and need for additional data in order to further our understanding of social, economic and political dynamics in the region. This is the first critical assessment towards understanding the Zhizo settlement of the Mapungubwe landscape.

\section{Background}

It had previously been thought that the initial occupation of the region by Zhizo farmers, around AD 900, was for agricultural purposes. DENBOw (1984) argued that it was in fact cattle and the region's high carry-

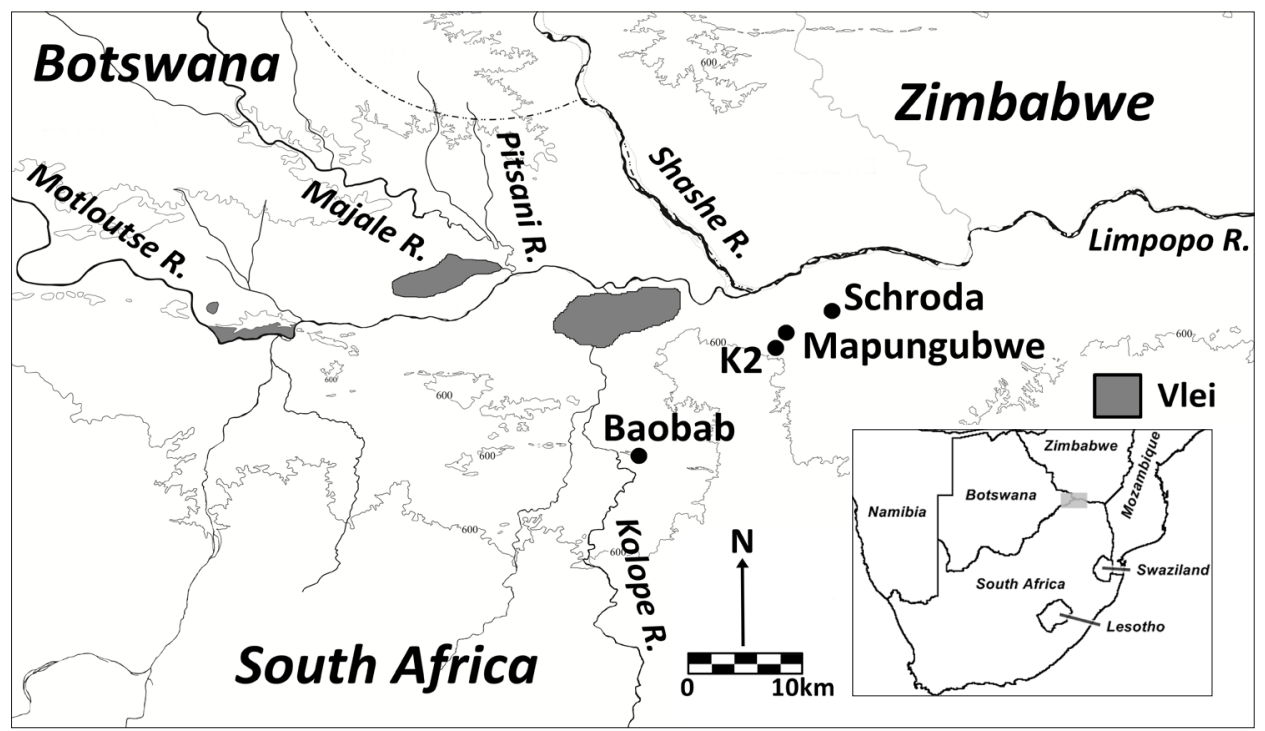

Fig. 1. The Greater Ma-pungubwe Landscape and prom inent agricul-turalist settlem ents. 


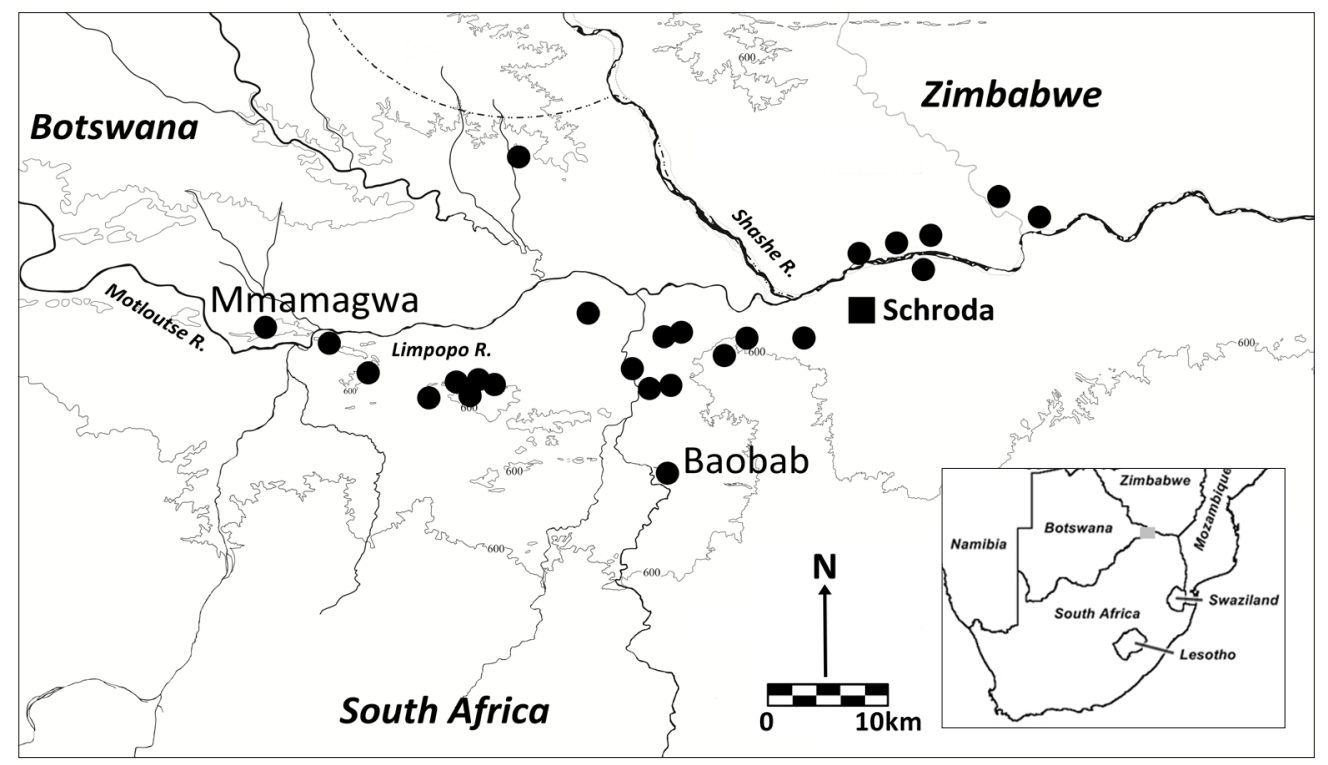

Fig. 2. Zhizo set-tlements on the G reater Mapun-gubwe Landscape (adapted From Hurrm an 2000).

ing capacity that led to agriculturalist settlement of the Limpopo Basin. Cattle are used as bride wealth amongst Eastern Bantu-language speaking farmers (Hall 1986), and Denbow (1984) suggested that the local cattle population increased, which eventually lead to the establishment of larger polities and state formation. Unfortunately, there is no evidence strongly suggesting this to have been the case: DenBow's (1984) argument is based on findings at Toutswe sites in Botswana, which post-date the initial Zhizo occupation (see CALABrese 2000). Instead, as will be shown, it has been argued that there is sufficient data to suggest that the area was occupied for trade purposes and in such a way so to maximise mercantile enterprises (e.g., Huffman 2000; Du Piesanie 2008).

The evidence that HufFMAn $(2000,2009)$ refers to is specifically the material record and Zhizo settlement pattern. In the case of the former, the Zhizo occupation levels of Schroda, which excludes the later Leokwe period occupation (CALABRESE 2007), yielded a large sample of glass beads, many of which were identified as Zhizo series beads from Southeast Asia (Wood 2000, 2005). These beads were transported by merchants along the East African coastline en route to Sofala, at the southern extremity of the trade winds (HUFFMAN 2007). The likely location of this trade post is in the Bazaruto Archipelago in Mozambique, near to modern day Vilanculos, and is known archaeologically as Chibuene (SINClaIR 1982; SinclaIR et al. 2012). Here archaeologists have found glass beads, Persian pottery, Islamic glass and glazed and unglazed pottery, which likely originated from coastal Swahili towns further north (SINCLAIR 1982). Foreign traders did not venture further south due to the limits of the wind systems (HuFFMAN 2007). It is entirely possible that the Greater
Mapungubwe Landscape was the first region in the interior of southern Africa that was directly linked to the East Coast trade network (HuFfmAn 2000). The key exports were ivory, skins and later gold and possibly other perishable goods, which have not been preserved archaeologically (VoIGT 1981).

Looking specifically at the settlement pattern of the region, it has been argued that most Zhizo homesteads do not cluster around the Limpopo floodplain, or more specifically, the fertile wetland area (DU PIESANIE 2008), which flooded seasonally (HuFFMAN 2008). One would expect the location of settlements to be near fertile land if agriculturalists were primarily interested in cultivation. The wetland areas are a unique feature of the local landscape and offered prime fertile land (see Scoones 1991). These nutrient rich zones could have been used to offset unfavourable environmental conditions, such as during years of little rainfall and drought (SMith et al. 2007). There have been a few Zhizo period sites identified near fertile ground, which were presumably planted with sorghum and millet, the primary crops during this time (HufFMAn 2000). One of these examples is Baobab, found on a sandstone ridge overlooking the Kolope River drainage basin (CAlabrese 2000; Fig. 2). Huffman (2009) suggests these sites were the exceptions and that, despite the lack of oxen or other modes of transport, all carbohydrate requirements were traded inwards. This, we feel, seems unlikely considering the fertile areas on the landscape, and that, despite low annual rainfall, there are a number of features that can offset poor precipitation levels (SMITH et al. 2007), which are discussed in detail in the following section. These resources meant that trade for grain could have easily been avoided. In addition, the site distribution analysis only includes sites that 


\begin{tabular}{|c|c|c|}
\hline TYSON \& LINDESAY (1992) & Period (AD) & Sмітн (2005) \\
\hline \multirow{2}{*}{ Cool and dry } & 100 & \\
\hline & 200 & \\
\hline \multirow{2}{*}{ Warm and wet } & 250 & \\
\hline & 600 & \\
\hline Variably cool and dry & 880 & \multirow{2}{*}{$\begin{array}{l}\text { Rainfall } 350 \text { to } 450 \mathrm{~mm} \text {; variability; } \\
\text { comparable to modern conditions }\end{array}$} \\
\hline \multirow{4}{*}{$\begin{array}{l}\text { Medieval warm epoch: } \\
\text { generally warm and dry }\end{array}$} & 900 & \\
\hline & 1010 & \multirow{2}{*}{$\begin{array}{l}\text { General increase in rainfall only felt } \\
\text { by } A D 1190=450 \text { to } 500 \mathrm{~mm}\end{array}$} \\
\hline & 1290 & \\
\hline & 1300 & \\
\hline \multirow{4}{*}{$\begin{array}{l}\text { Little Ice Age: cool and dry } \\
\text { except for a warming period } \\
\text { from AD } 1500 \text { to } 1675\end{array}$} & 1310 & \multirow{2}{*}{$\begin{array}{l}\text { Rainfall seems to be consistently } \\
\text { above } 500 \mathrm{~mm}\end{array}$} \\
\hline & 1415 & \\
\hline & 1475 & \multirow{2}{*}{$\begin{array}{l}\text { Marked decrease in rainfall to } 350 \text { to } \\
450 \mathrm{~mm} \text {; comparable to AD } 900\end{array}$} \\
\hline & 1685 & \\
\hline \multirow{2}{*}{$\begin{array}{l}\text { Ameliorating post-Little Ice } \\
\text { Age conditions }\end{array}$} & 1850 & \\
\hline & Present & \\
\hline
\end{tabular}

Tab. 1. A comparison of climatic data from TySON \& LiNDESEY (1992) and SMITH (2005); note the lack of congruency between their finds.

are visible on the surface (Du PIESANIE 2008), and we do not yet know how much ivory was traded - only the Zhizo levels at Schroda (HANISCH 1980: 332), and few other contemporaneous homesteads contained ivory, such as at Schoemansdal (Plug et al. 2000) or Boitsemagano, Molokwane and Mabjanamatshwana near Rustenberg (PLUG \& BADENHORST 2006). Some of the ivory finds could have also been for personal use. Thus, at best, the trade argument in terms of acquiring food is preliminary. We now turn to look more specifically at the local environment and how it was capable of supporting agricultural practices.

\section{Climate and landscape}

The Greater Mapungubwe Landscape currently experiences variable climatic conditions ( Вмiтн et al. 2007), but, based on palaeoclimatic evidence, certain trends have persisted over the region (Tab. 1). Widespread cool and dry conditions existed over northern South Africa between AD 600 and 900 (TYSON \& LINDESAY 1992), unfavourable for cultivation (HuFFMAN 2008). During this period archaeological evidence in the region suggests that the area was sparsely populated by agriculturalists, but this may not be a true reflection of the region's settlement since it is only based on surface finds (HufFman 2000). Only rainmaking hills, where rituals were performed by farmers to control rain, and which contain broken ceramics (HUFFMAN 2009) and a smithing site (Forssman 2013) have been found, but no evidence of homesteads. From AD 900, however, the climate improved (Sмітн 2005) and annual rainfall was expected to have increased to between 350 and $450 \mathrm{~mm}$, albeit that this seems to have varied across the landscape. For example, some $\delta^{15} \mathrm{~N}$ values from faunal samples indicated periods with over $500 \mathrm{~mm}$ of rainfall per year at certain locations (SмITH et al. 2007). Variation in precipitation levels across the landscape would allow for the implementation of strategies to reduce the risk of crop failure, for example, by planting in different micro-environments. The increased rainfall and its spatial variation could lead one to suggest that these conditions contributed to the region's settlement. However, Sмiтh's (2005: iii) nitrogen isotope data seems to suggest that changes in the farmer sequence were not linked to precipitation levels, implying independent and unrelated economic shifts possibly indicating that trade, politics, and the opportunities that an 'unoccupied' landscape offered were responsible (see SмIтн et al. 2007).

The local floral and faunal populations offered a viable and year-round resource for human groups to rely upon, whether they were farmer or foragers. Mopane veld (Colophospermum mopane) dominates the local landscape and is a straight-growing tree ideal not only for construction (MANYANGA 2006: 44), but also as fuel (VAN WYK et al. 2008) and has many associated religious beliefs and medicinal uses (see RoodT 1998; VAN WYK et al. 2008). Mopane trees also develop natural hollows, which a wide diversity of mammals and birds use, and water is known to collect in these spaces (RoodT 1998). Most significantly, it is fed upon by mopane worms (actually a caterpillar; Gonimbrasia belina), which appear in large numbers during late summer and spring. These are considered a local delicacy and can be dried and stored for many months (RooDT 1998; VAN WYK et al. 2008), providing an important source of protein. This tree alone is a key feature of the local environment, but it is not the only valuable species in the area. Other important tree species are marula trees (Sclerocarya birrea), which flower in spring (VAN WYK \& VAN WYK 2007), and produce a fruit more nutritious than oranges; shepherd's tree (Boscia spp.), which also has a highly nutritious fruit that appears in spring; and the baobab (Adansonia digitata), which produces a 
large fruit from summer to spring. The shepherd's tree and baobab both have large cavities, particularly the latter, which hold water for many months into the dry season. The baobab is a local species used as food by a number of animals, including elephants (ROODT 1998). In addition to these species there is a variety of other usable plant resources in the area (see G. ALEXANDER 1984; MANYANGA 2006 for reviews), all of which made the region suitable for human settlement.

Topography also plays a major role in the ecological structure of the landscape, and significantly provides outlets for cultivation even in times of low rainfall. The gentle gradient supports deposition cycles renewing the nutritional value of soils in and around floodplains (HANISCH 1981). Along parts of the Limpopo and Motloutse Rivers is a zone of exposed Clarens sandstone (G. Alexander 1984), covering an area of more than $1000 \mathrm{~km}^{2}$ (BORDY \& CATUNEANU 2002), and includes numerous ridges and koppies (inselbergs) as well as exposed dolerite dykes (LE BARON et al. 2011). Within the sandstone belt are a number of micro-ecological niches, supporting a number of specialist and unique species. Such niches may have been utilised by agriculturalists as well as by foragers and wildlife (HANISCH 1981). There is also delayed water flow in these areas due to water filtering from the sandstone areas into the lower lying flat areas, maintaining moisture levels in these zones and occasionally resulting in temporary wetlands within the sandstone areas (MANYANGA 2006: 41). The vlei areas on the southern banks of the Limpopo River and along the Majale, Motloutse and Shashe Rivers could have been used during harsh climatic periods due to the nutrient rich and fertile soils, adequate moisture levels and high productivity. Furthermore, the rivers sources are located in relatively high rainfall zones and therefore even in years of poor rainfall in the region, large volumes of water drain down the rivers and tributaries (MANYANGa 2006: 41). Thus, the local topography, rivers and vleis offer a unique coping mechanism for periods of poor rainfall (e.g., SCOONES 1991; ManYanga 2006; SMith et al. 2007).

In summary, the local landscape includes a number of features that would have favoured local settlement. They are the local vegetation communities (e.g., sweet veld; MUCINA \& RUTHERFORD 2006), the large wildlife populations that inhabit savannah biomes (see HunTLEY 1984) and the network of tributaries bisecting the landscape and perennial rivers such as the Limpopo, Motloutse and possibly the Shashe. These rivers also replenish the soils with nutrients, further supported by evidence of colluvial action over the relatively flat landscape (HANISCH 1981). Lastly, the floodplains surrounding the river systems were large enough to sup- port the Mapungubwe capital, expected to have been around 11,000 people between AD 1220 and 1300 based on the number of homesteads in the area, and so would have presumably supported the Zhizo population, of approximately 1075 people (see HUFFMAN 2008 for population figures). We now turn to the elephant data, to assess whether the local elephant population was large enough to endure heavy exploitation.

\section{Elephant on the Greater Mapungubwe Landscape}

At the onset it must be made clear that this data is based on the modern elephant population on the Greater Mapungubwe Landscape, and on other finds made across Africa. It is obvious, which we acknowledge, that this information is not entirely comparable with elephant population dynamics during the Zhizo period. In fact, if anything it is a gross under-representation of what the elephant population may have been around AD 900, and should be considered a minimum. We feel, however, that with these data we have the unique ability to make fairly accurate predictions about past elephant populations, and from it demonstrate that trade could have been supported and that scavenging of elephant carcasses could have been used to supplement ivory trade stocks.

\section{Distribution}

Faunal evidence from archaeological sites around southern Africa suggests that elephants were widespread in the region (Plug \& BADENHORST 2001), and that their numbers remained high in most areas until large-scale hunting and ivory trade began in the twentieth century (e.g., Skead et al. 2007; Carruthers et al. 2008). Modern human population densities, fences and activities such as hunting and agriculture, which may reduce carrying capacity (MILNER-GULLAND \& BEDDINGTON 1993), have considerably altered elephant population numbers and distribution (HALl-MarTIN 1992; HoARE \& Du ToIT 1999; van AARDE et al. 2005; MBAIWA \& MBAIWA 2006). It is not necessary to review elephant biology, behaviour and habitat preferences here, this can be found elsewhere (see Scholes \& Mennell 2008 for a review); we instead focus specifically on elephant population, their mortality rate and tusk size.

\section{Population and mortality}

The current Greater Mapungubwe Landscape elephant population utilises an area of approximately $2016 \mathrm{~km}^{2}$ with an average density of 0.61 elephants $/ \mathrm{km}^{2}$, but in certain areas this density is as high as 1.22 elephants $/ \mathrm{km}^{2}$ 


\begin{tabular}{|c|c|c|c|c|c|c|c|c|c|c|c|c|}
\hline Age & \multicolumn{2}{|c|}{0} & \multicolumn{2}{|c|}{$1-9$} & \multicolumn{2}{|c|}{ 10-19 } & \multicolumn{2}{|c|}{ 20-29 } & \multicolumn{2}{|c|}{$30-44$} & \multicolumn{2}{|c|}{$45-60$} \\
\hline Sex & SR & $\mathrm{M}$ & SR & $\mathrm{M}$ & SR & M & SR & M & $\mathrm{SR}$ & $\mathrm{M}$ & SR & M \\
\hline $\mathbf{F}$ & 0.1 & 0.06 & 0.1 & 0.01 & 0.2 & 0.02 & 0.1 & 0.01 & 0.05 & 0.03 & 0.02 & 0.05 \\
\hline $\mathbf{M}$ & 0.1 & 0.06 & 0.1 & 0.01 & 0.1 & 0.02 & 0.1 & 0.01 & 0.03 & 0.03 & 0.01 & 0.05 \\
\hline
\end{tabular}

Elephant density: $0.61 / \mathrm{km}^{2}$

\begin{tabular}{lcr} 
Age & \multicolumn{2}{c}{0} \\
Sex & No. & Car \\
F & 2242 & 13 \\
M & 2185 & 13 \\
& & \\
Total: & $\mathbf{4 4 2 7}$ & $\mathbf{2 6}$ \\
& \multicolumn{2}{c}{$>9$} \\
Age & No. & Ca \\
Sex & 5390 & 11 \\
F & 3909 & 80 \\
M & & \\
& $\mathbf{9 3 0 0}$ & $\mathbf{1 9}$ \\
Total: & &
\end{tabular}

\begin{tabular}{cc}
\multicolumn{2}{c}{$1-9$} \\
No. & Car. \\
2242 & 22 \\
2185 & 22 \\
4427 & 44 \\
&
\end{tabular}

\begin{tabular}{|c|c|c|c|c|c|c|c|}
\hline \multicolumn{2}{|c|}{$10-19$} & \multicolumn{2}{|c|}{$20-29$} & \multicolumn{2}{|c|}{$30-44$} & \multicolumn{2}{|c|}{$45-60$} \\
\hline No. & Car. & No. & Car. & No. & Car. & No. & Car. \\
\hline 3105 & 62 & 1188 & 12 & 920 & 28 & 287 & 14 \\
\hline 2089 & 42 & 1016 & 10 & 632 & 19 & 172 & 9 \\
\hline 5193 & 104 & 2204 & 22 & 1552 & 47 & 460 & 23 \\
\hline \multicolumn{6}{|c|}{ Total tusk-bearing elephants ( $>9$ years): } & 9300 & \\
\hline \multicolumn{6}{|c|}{ Total number of tusks (1.9/elephant): } & 17,669 & \\
\hline \multicolumn{6}{|c|}{ Total weight of tusks (average $7.4 \mathrm{~kg}$ ): } & 131,458 & \\
\hline \multicolumn{6}{|c|}{ Total carcasses of tusk-bearing elephant ( $>9$ years): } & 194 & \\
\hline \multicolumn{6}{|c|}{ Total number of tusks on carcasses (1.9/elephant): } & 369 & \\
\hline \multicolumn{6}{|c|}{ Total weight of tusks on carcasses (average $7.4 \mathrm{~kg}$ ): } & 2742 & \\
\hline
\end{tabular}

Elephant density: $1.22 / \mathrm{km}^{2}$

\begin{tabular}{|c|c|c|c|c|c|c|c|c|c|c|c|c|}
\hline Age & \multicolumn{2}{|c|}{0} & \multicolumn{2}{|c|}{$1-9$} & \multicolumn{2}{|c|}{$10-19$} & \multicolumn{2}{|c|}{$20-29$} & \multicolumn{2}{|c|}{$30-44$} & \multicolumn{2}{|c|}{$45-60$} \\
\hline Sex & No. & Car. & No. & Car. & No. & Car. & No. & Car. & No. & Car. & No. & Car. \\
\hline $\mathbf{F}$ & 4484 & 269 & 4484 & 45 & 6209 & 124 & 2376 & 24 & 1840 & 55 & 575 & 29 \\
\hline $\mathbf{M}$ & 4369 & 262 & 4369 & 44 & 4178 & 84 & 2031 & 20 & 1265 & 38 & 345 & 17 \\
\hline Total: & 8854 & 531 & 8854 & 89 & 10,387 & 208 & 4408 & 44 & 3105 & 93 & 920 & 46 \\
\hline Age & \multicolumn{2}{|c|}{$>9$} & & & \multicolumn{6}{|c|}{ Total tusk-bearing elephants ( $>9$ years): } & 18,599 & \\
\hline Sex & No. & Car. & & & \multicolumn{6}{|c|}{ Total number of tusks (1.9/elephant): } & 35,338 & \\
\hline $\mathbf{F}$ & 10,780 & 227 & & & \multicolumn{6}{|c|}{ Total weight of tusks (average $7.4 \mathrm{~kg}$ ): } & 262,916 & \\
\hline M & 7819 & 159 & & & \multirow{2}{*}{\multicolumn{6}{|c|}{$\begin{array}{l}\text { Total carcasses of tusk-bearing elephant }(>9 \text { years }) \text { : } \\
\text { Total number of tusks on carcasses (1.9/elephant): }\end{array}$}} & 386 & \\
\hline & & & & & & & & & & & 734 & \\
\hline Total: & 18,599 & 386 & & & \multicolumn{6}{|c|}{ Total weight of tusks on carcasses (average $7.4 \mathrm{~kg}$ ): } & 5461 & \\
\hline
\end{tabular}

Tab. 2. Natural age and sex specific mortalities at two different densities and the number of tusks and tonnage available as a result (SR: sex ratio; M: mortality; Car.: number of carcasses).

(SELIER et al. 2014). Using these two density figures, it is possible that within $100 \mathrm{~km}$ of the Limpopo and Shashe River's confluence, an area of $31,416 \mathrm{~km}^{2}$, there may have been an elephant population of between 19,164 and 36,527 individuals. It is highly likely that the average density was in fact higher than it is today since elephant movement and distribution is currently heavily restricted by humans (HoARE \& DU ToIT 1999; van Aarde $e t$ al. 2008; Graham et al. 2009; Selier et al. 2014). During the first and beginning of the second millennia $\mathrm{AD}$, this impact would have been less intensive since the local human population was low; elephants may have maintained much of their original mobility habits, possibly only avoiding agriculturalist homesteads. While all male elephants carry tusks, only $98 \%$ of females possess them (STEENKAMP et al. 2007), which means that within a population the average adult elephant carries 1.9 tusks. We would therefore expect between 9300 (0.61 elephants/ $\left.\mathrm{km}^{2}\right)$ and 18,599 (1.22 elephants $/ \mathrm{km}^{2}$ ) tusk-bearing elephants in the area. We can then use the average mortality rate recorded in elephant populations, found to be between 1 and $5 \%$ per annum (see Moss 2001; VAN AARDE et al. 2008), to calculate the number of carcasses on the landscape and the number of collectable tusks. Based on this, there may have been between 194 and 386 tusk-bearing carcasses available for exploitation per year, resulting in between 369 ( $1 \mathrm{tusk} / 85 \mathrm{~km}^{2}$ [using $31,416 \mathrm{~km}^{2}$ ]) and 734 (1 tusk/43 km²) actual tusks (Tab. 2).

\section{Tusk weight}

The largest recorded tusks are 102.3 and $97 \mathrm{~kg}$ from a single individual shot in 1898 at Mt. Kilimanjaro (SKinner \& Smithers 1990; WARD 1992: 803). In southern Africa, however, the largest tusks were found in KwaZulu-Natal and were collected by the Parks Board in 1988 and weighed 71.2 and $63.5 \mathrm{~kg}$ (WARD 1992: 804). A notable find of two tusks was made along the Limpopo River in 1973, each weighing little over 64 kg (BEST \& BEST 1977; WARD 1992: 804). Other than these examples found somewhere along the Limpopo River (the report is not specific), there are 
no recorded tusks that were either acquired through hunting or found in the field between 1882 and 1992 in WARD's (1992) records that exceed $36.5 \mathrm{~kg}$ and were found in/near what we call here the Greater Mapungubwe Landscape.

Elephant tusks regularly reach, and exceed, $60 \mathrm{~kg}$ in large males, whereas female tusks average around $10 \mathrm{~kg}$. However, of the tusks seized by anti-poaching organisations in Africa between 1989 and 2004, the average tusk weight per individual was $7.4 \mathrm{~kg}$ (STILES 2004), whereas in 1970 the average tusk weight was $12 \mathrm{~kg}$ (SKInNeR \& SMITHers 1990); in the mid-19 ${ }^{\text {th }}$ century William Finaughty shot 95 elephants totalling $2200 \mathrm{~kg}$ of ivory, translating to $11.6 \mathrm{~kg} / \mathrm{tusk}$, possibly suggesting that until the ivory boom in 1872 and subsequent poaching, there was no major decline in average tusks weights (CARRUTHERs et al. 2008). If the average tusk weight of $7.4 \mathrm{~kg}$ is used to calculate potentially available ivory in the region there would have been between 131 and 260 tonnes of tusks locally available with 2742 and $5461 \mathrm{~kg}$ recoverable from carcasses per annum (Tab. 2). For comparative purposes, if we use $12 \mathrm{~kg}$ as the average tusk weight, we would expect over 212 and possibly as much as 424 tonnes of ivory to have been available around the confluence area and $4423-8808 \mathrm{~kg}$ from carcasses. These figures are considered a minimum and so, if trade could be supported based on these figures, it certainly would have been possible during the Zhizo period when tusk weights were presumably much higher.

\section{Discussion}

The challenge with this study is the quality of available data. We have created a model to predict the size of the elephant population in the area along with the likely mortality rate of tusk-bearing individuals; there is no reason to believe the natural mortality rate has significantly changed. However, this is based on modern data and so is not entirely comparable. In addition, there is an altogether lack of ethnographic data and historic accounts, for the region, from travellers, missionaries or hunters. Had this not been the case we would have been able to incorporate these reports into our model, even though some would no doubt have been anecdotal. While our data has certain limitations, it is at present the only critical assessment of the trade explanation, and the only attempt at questioning a conclusion previously made and accepted without strong data. This paper is thus the first to provide data that can be incorporated into the debate on the initial occupation by agriculturalists of the Greater Mapungubwe Landscape. Below we provide some thoughtful comments on our findings and develop a hypothesis that requires additional testing.

\section{Ivory trade: hunting elephants and elephant mortality}

There is no reason to discount that ivory played a prominent role on the Greater Mapungubwe Landscape's economy in a similar way that it has contributed to shaping elephant populations across Africa (CARRUTHERs et al. 2008: 28). While both African and Asian elephants (Elephas maximus) produce ivory that is opaque, flexible and fine-grained, it is from African elephants that the ivory is most suitable for the production of artefacts (LuxMOORE 1991; AlPERs 1992; MEREDITH 2001). It was only since the sixteenth century, but mostly from the twentieth century, that the demand for elephant ivory has been unprecedented, threatening the survival of both African and Asian elephant species (e.g., BeACHEY 1967; PARKER \& MARTIN 1982; NTUMI et al. 2009). For the purpose of this paper, we are concerned with the period around AD 900 and the role elephants played in southern Africa, where unfortunately elephant use, whether for food or as a resource, is poorly documented (see HAMMOND-TOOKE 1974; MitCHELl 2005).

If Zhizo farmers did settle on the Greater Mapungubwe Landscape to exploit the local elephant population for trade purposes, then there should have been a viable population available to them for sustainable ivory exploitation. Recent studies in the area allow us to make fairly accurate predictions of the local elephant demographics and, as Table 2 shows, this demonstrates that there was likely a large enough elephant population and tusk tonnage available to Zhizo period farmers. Unfortunately we do not have the luxury of using historical accounts to aid in population estimates since there are very few accounts and where they do exist are anecdotal and of little use.

Would this have been enough with which to supply the Indian Ocean trade network? We do not know the extent of items exported from the area (PLUG 2000) and cannot say since no records from around AD 900 exist. Furthermore, the archaeological record of Schroda requires further analysis to separate the Zhizo and later Leokwe occupations of the site. At present much of our understanding of the site is a conflation of this information, and based on a poor understanding of the ivory assemblage - recent studies are revealing, in fact, far fewer ivory remains than previously thought (Annie Antonites, pers. comm. 2013). Further complicating the matter, it is not always possible to separate personal and trade items. However, based on more recent evidence, it was recorded that from 1512 to 1515 Portuguese traders exported 69 tonnes of ivory from Beira (SpINAGE 1973). Alternatively, BEACHEY (1967) reports a much lower figure of 13 tonnes of ivory that passed through Sofala in the $16^{\text {th }}$ century. SPINAGE's (1973) figures translate to 
$17,250 \mathrm{~kg}$ of ivory per annum, which was presumably sourced from a larger area (NTUMI et al. 2009), and not only the Greater Mapungubwe Landscape. Possibly more comparable is the $90,000 \mathrm{~kg}$ of tusks exported from the Transvaal in 1855 (CARRUTHERs et al. 2008). If we use a $7.4 \mathrm{~kg} /$ tusk average, this translates to 12,162 tusks while at $12 \mathrm{~kg} /$ tusk this rises to 7500 tusks over the entire province, some $288,000 \mathrm{~km}^{2}$, and which includes the entire Greater Mapungubwe Landscape. Therefore, $3.2 \mathrm{~kg}$ of ivory per square kilometre was being exported from the Transvaal. In the area that we have selected for our study, which covers $31,416 \mathrm{~km}^{2}$, there was possibly between 4.2 and $8.4 \mathrm{~kg}$ of ivory per square kilometre using $7.4 \mathrm{~kg}$ as an average tusk weight, therefore exceeding the demands of the entire Transvaal province in the $19^{\text {th }}$ century. This comparison is only somewhat useful, and we do not suggest that the tonnage of ivory exported during the Zhizo period was comparable, in fact it was likely far lower since hunters back then did not have access to rifles or an effective transport system. It does serve to show that based on our estimates, and its comparison to more recent ivory trading, the Zhizo elephant population was likely large enough to support trade endeavours around AD 900.

Considering the possible size of the local elephant population, one wonders how natural elephant mortality could have supplemented ivory trade. Hunting large animals such as elephants is a dangerous activity, even though skilled hunters know how to reduce the risks (Grosse-Woodley 2008), and the option to scavenge tusks from naturally occurring carcasses is simple and relatively risk free. Based on modern estimates, which are under-representations of the elephant population during Zhizo times, there was possibly one tusk every $43-85 \mathrm{~km}^{2}$. Using an average of $7.4 \mathrm{~kg}$ and $12 \mathrm{~kg}$ per tusk, between 2742 and $5461 \mathrm{~kg}$ and 4423 and $8808 \mathrm{~kg}$, respectively, of tusks could have been collected each year from carcasses. While the tonnage is fairly high, even as a minimum figure, the density remains low and so scavenging would have to have been wide-spread and co-ordinated to contribute meaningfully to ivory trade.

We, thus, suspect that scavenging was combined with hunting in order to acquire the amount of tusks needed for trade (see PLUG 2000). The process of capturing and successfully killing an adult elephant relies on formalised practices used to good effect (briefly discussed below but see GRÖNING \& SALLER 1999) and disadvantaging the animal to give the hunter the ability to dispatch the individual. Across Africa a variety of hunting methods have been practiced. Amongst certain hunter-gatherers hand spears are used, provided there is time to deliver multiple well-placed stabs (CHURCHILl 2008). In East Africa, the Dorobo used pit-fall traps to capture elephants and buffalo (Syncerus caffer) and the Suk and Bari elevated themselves using platforms and climbing trees, respectively, under which the animals were driven and then speared (see HunTINGFORD 1953a, 1953b; Prins 1992). In al-Mas'udi's recount of his travels to Persia, India, China and Oman following the eastern African coastline, he reported that people along the southern Kenyan/northern Tanzanian coast hunted elephant with long spears and did not use the ivory for any function other than for trade or sale (FrEeman-GreENVILle 1962: 14). In other cases poison is used along with arrows and spears to kill the animal (MARKs 1977; GRÖNING \& SALLER 1999).

As mentioned, there are few accounts of elephant hunting in the Mapungubwe area, and certainly not for the period in question. One example is Selous (1881: 26) who passed through the region between 1877 and 1880, crossing the Motloutse and Shashe Rivers, and saw no animals of interest. Perhaps, however, the most comparable account is that found in THEAL's (1901: 321-323) report to the government of the Cape Colony on south-eastern Africa. Unfortunately he discusses various finds from most of the east African coastline and is not specific in the text about the area to which he is referring. Nevertheless, he states that along the coastline elephants destroyed plantations also recorded in other parts of Africa (e.g., CHIYO et al. 2005; JACKSON et al. 2008; NYHUS et al. 2008) and for this reason were exterminated in a number of ways (see JACKSON et al. 2008). The safest method to hunt elephants was to dig pits along thickets and cover them in branches; once an elephant fell into the large cavity it was trapped and could be dispatched inside the pit. Another method was to use iron-pointed spears and disembowel an individual while it slept. The following day the animal would be tracked down and killed, if it had not died by that stage. At this point the extended community settled around the carcass and feasted upon it, according to THEAL (1901: 322), for up to three days. He further states that the other two principle reasons to kill an elephant are to consume its meat and sell the ivory, of which at the time of his visit more than 35.5 tonnes were being sent to India. There is no additional information in THEAL's (1901) report that would assist in reconstructing the local elephant population on the Zhizo landscape.

Regarding past consumption of elephant meat, there is ample evidence across Africa indicating how an elephant carcass would be used. Firstly, a male elephant provides up to $5000 \mathrm{~kg}$ of meat, whereas a female produces $2704 \mathrm{~kg}$ (MARKS 1973). Meat could be consumed, traded with or used as payment to hunters or even labourers (see VoIGT 1981; for a modern example see GRESSIER 2012). Other useful items include the skin (to 
cover shields and drums and to make belts), the tendons (used as cordage or thread) and the bones (which, like the tusks, could be carved into tools or items of ritualistic significance; GRÖNING \& SALLER 1999). Items such as the feet and trunk may also have been used. Hunting elephants, therefore, not only gave people access to trade goods but may also have featured in rituals, management strategies and, if successful, provided people with a large supply of meat and other resources.

Turning to the data from the Greater Mapungubwe Landscape, had elephants been hunted, or even scavenged, one might expect to find evidence of their remains at archaeological sites, such as bones, or the presence of kill or butchery sites. In central Europe and during the Clovis era in North America, people left behind sites dominated by elephant remains (HAYNES \& Klimowicz 2014). The same was found at an Upper Acheulian butchery site at Lehringen, near Bremen in Germany (Movius 1950), at Gesher Benot Ya'Aqov in Israel (GOREN-INBAR et al. 1994), in Kent, United Kingdom (Wenban-Smith et al. 2006) and in Spain, such as at the Middle Pleistocene site of Aridos (VILLA 1990; Yravedra et al. 2010). At Ambrona, also in Spain, there are between 30 and 35 elephants with evidence of butchery even though only a few associated stone tools were found (Howell 1966). In Malawi, Clark \& HaYnes (1970) report on a kill site where a single elephant was found with a number of associated Middle Stone Age tools. It seems that in areas where elephants were killed their remains are found in the archaeological record.

One then wonders why, if elephant hunting for the purpose of intensive trade did occur during the Zhizo period, we find no evidence of this in terms of specialist tools and faunal remains other than ivory manufacture. We should also expect the ivory finds to be fairly abundant in the archaeological record, but this isn't the case. In KwaZulu-Natal at Kwagandaganda what appears to be the largest sample of ivory chips, with no artefacts, was recovered, comprising of close to 2000 pieces altogether weighing 4262.5 g (Beukes 2000). Kwagandaganda dates to between AD 620 and 780, so precedes the Zhizo period by over 100 years. Ndondondwane, another site in KwaZuluNatal, dates to AD 780 and 970 and contained an entire elephant tusk and an ivory bracelet. In Kruger National Park, between AD 470 and 900, there is no evidence of ivory at any of the excavated sites reported on in PLUG (1989), despite the appearance of other trade items including glass beads and east coast marine shell. Therefore, ivory is not required to enable trade. Later, in the same region at Thulamela, occupied between AD 1350 and 1750, there is some evidence of elephant remains in the faunal record with 149 identified skeletal remains, which includes bones and ivory from four individuals (PLUG 2000), the tusks of which, using our estimates, would have at least weighed between 59.2 and $96 \mathrm{~kg}$ in total. The deficit of data indicating that ivory was a significant trade item on the Greater Mapungubwe Landscape and in the neighbouring region, when compared to Kwagandaganda for example, possibly suggests that we need to be more critical of the trade argument.

It is highly likely that the elephant population was large enough to support Zhizo-period trade endeavours, but there is currently no strong evidence in the archaeological record indicating extensive trade in ivory (Annie Antonites, pers. comm. 2013). Therefore, we feel that the conclusion that farmers settled the area to trade ivory lacks the appropriate data in terms of material remains on the Greater Mapungubwe Landscape and across southern Africa prior to the arrival of Europeans. Why, then, settle in the Mapungubwe region? First and foremost, the Greater Mapungubwe Landscape is a productive system that was not only able to support a large elephant population, but a diversity of other plant and animal resources used for the production of artefacts, medicines and construction, not to mention consumption; some agriculturalist homesteads indicate that it was wild game that farmers mostly relied on, rather than their domesticated stock (e.g., VoIGT \& PLUG 1981; TURNER 1987; MANYANGa et al. 2000). There are a number of environmental features in the area, such as perennial rivers, active tributaries and the vlei areas, which would have lessened the effect that poor rainfall had on the region. Periodic flooding, to which the area is prone (SMITH 2005), deposited nutrient rich soils creating and sustaining fertile floodplains and the vlei areas were suitable for plant growth of both cultivated and natural species. These areas were heavily relied on during the Mapungubwe period and would have been sufficient during Zhizo times. If cultivation was not occurring on a scale large enough to support the local population, supplementary food supplies would need to have been imported, and linked to this, which we do not discuss here, is from where and how? Zhizo period farmers did not have oxen or animals to transport crops and there would have been too much needed to support the population to carry it entirely; farming had to have occurred at a sustainable level to support local carbohydrate requirements (see NoLI \& AVERY 1988). The landscape was also particularly amenable to hunting and a wide diversity of species was present, far easier to hunt than elephant. Lastly, foraging people, as well as previous pioneer agriculturalist groups who lived and may still have been living in the area (HALL \& SMITH 2000), could have assisted a new group settling on the landscape by offering services, sharing local knowledge (e.g., J. AleXAnder 1984) and 
trading with hides, jewellery and subsistence products (HALl \& SMiTH 2000) or by acting as ritual specialists (Forssman 2014). Thus, the landscape had a number of features and resources making it attractive for agriculturalist settlement and one of these was the large elephant population.

\section{Conclusions}

HuFFMAN's (2000) suggestion that the Greater Mapungubwe Landscape was settled by Zhizo agriculturalists to access its large ivory reserves has gone unchallenged in the literature. In this paper we have suggested that the landscape has unique ecological characteristics and resources that made the region suitable for agriculturalist settlement. These resources are a wide range of wildlife that could be hunted or trapped, a variety of wild plant resources that could be gathered as food, for building, carving or for medicinal purposes, year round water supplies, cultivatable zones and access to a large supply of ivory. The extensive riparian, colluvial and vlei environments were ideal for elephant populations (CHAMAILlE-JAMMES 2007; LOARIE et al. 2009a, 2009b; SHANNON et al. 2009) and their ivory was used for trade purposes, along with many other locally available resources. With this in mind, we believe that the landscape was highly suited to agricultural settlement, with an elephant population that was likely large enough to support trade, and provide a further stimulus for settlement.

Future studies should focus on assessing the extent of the ivory trade and whether the Greater Mapungubwe Landscape was favoured over other areas which hosted large elephant populations, such as further east along the Limpopo River in what is now Kruger National Park or Mozambique. We suggest that known ivory finds from archaeological sites should be tested to ensure that they are made from elephant ivory rather than hippopotamus (Hippopotamus amphibius) or warthog (Phacochoerus africanus) tusks. Further, it would be interesting to know whether other Zhizo period sites contain evidence of ivory working, which might indicate trade, and whether kill or butchery sites are present.

\section{Acknowledgements}

The authors would like to thank the Mashatu Game Reserve for their assistance during the various stages of this research and particularly Pete le Roux. We thank Annie Antonites, Ashley Coutu, Grant Hall and Peter Mitchell for discussions and they are also thanked along with Tom Huffman for commenting on an earlier draft of this paper. All errors remain our own.

\section{References}

Alexander, G.J. 1984. A Preliminary Investigation into the Relationships Between Geology, Soils and Vegetation in the Eastern Tuli Block, Botswana. Unpublished Honours Report, University of Natal, KwaZulu-Natal.

Alexander, J. 1984. Early frontiers in southern Africa. In: Hall, M., Avery, G., Avery, D.M., Wilson, M.L. \& Humphreys, A.J.B. (eds.), Frontiers: Southern African Archaeology Today. BAR International Series 207. Oxford, pp. 12-23.

Alpers, E. 1992. The ivory trade in Africa: an historical review. In: Ross, D. (ed.), Elephant: The Animal and its Ivory in African Culture. University of California, Los Angeles, pp. 349-360.

Beachey, R.W. 1967. The East African ivory trade in the nineteenth century. Journal of African History 8 (2), 269-290. http://dx.doi.org/10.1017/S0021853700007052

Best, A.A. \& Best, T.G.W. 1977. Roland Ward Records of Big Game XVII Edition (Africa). Roland Ward, Sussex.

Beukes, C.F. 2000. Kwagandaganda: an Archaeozoological Study of Exploitation of Animal Resources During the Early Iron Age in KwaZulu-Natal. Unpublished MA Thesis, University of South Africa, Pretoria.

Bordy, E.M. \& Catuneanu, O. 2002. Sedimentology and palaeontology of upper Karoo aeolian strata (Early Jurassic) in the Tuli Basin, South Africa. Journal of African Earth Sciences 35 (2), 301-314. http://dx.doi.org/10.1016/S08995362(02)00103-3

Calabrese, J.A. 2000. Interregional interaction in southern Africa: Zhizo and Leopard's Kopje relations in northern South Africa, southwestern Zimbabwe, and eastern Botswana, AD 1000 to 1200. African Archaeological Review 17 (4), 183-210. http:// dx.doi.org/10.1023/A:1006796925891

Calabrese, J.A. 2007. The Emergence of Social and Political Complexity in the Shashi-Limpopo Valley of Southern Africa, AD 900 to 1300: Ethnicity, Class, and Polity. British Archaeological Reports, Oxford.

Carruthers, J., Boshoff, A., Slotow, R., Biggs, H.C., Avery, G. \& Matthews, W. 2008. The elephant in South Africa: history and distribution. In: Scholes, R.J. \& Mennell, K.G. (eds.), Elephant Management: A Scientific Assessment for South Africa. Wits University Press, Johannesburg, pp. 23-83.

Chamaille-Jammes, S., Fritz, H. \& Murindagomo, F. 2007. Climate-driven fluctuations in surface-water availability and the buffering role of artificial pumping in an African savanna: potential implication for herbivore dynamics. Austral Ecology 32 (7), 740-748. http://dx.doi.org/10.1111/j.1442-9993 $.2007 .01761 . x$

Chiyo, P.I., Cochrane, E.P., Naughton, L. \& Basuta, G.I. 2005. Temporal patterns of crop raiding by elephants : a response to changes in forage quality or crop availability? African Journal of Ecology 43 (1), 48-55. http://dx.doi. org/10.1111/j.1365-2028.2004.00544.x 
Churchill, S.E. 2008. Weapon technology, prey size selection, and hunting methods in modern hunter-gatherers: implications for hunting in the Palaeolithic and Mesolithic. Archeological Papers of the American Anthropological Association 4, 11-24.

Clark, J.D. \& Haynes, C. 1970. An elephant butchery site at Mwanganda's Village, Karonga, Malawi, and it's relevance for Palaeolithic archaeology. World Archaeology 1 (3), 390-411.

De Beer, Y. \& van Aarde, R.J. 2008. Do landscape heterogeneity and water distribution explain aspects of elephant home range in southern Africa's arid savannas? Journal of Arid Environments 72 (11), 2017-2025. http://dx.doi.org/10.1016/j. jaridenv.2008.07.002

Denbow, J.R. 1984. Cows and kings: a spatial and economic analysis of a hierarchal Early Iron Age settlement system in eastern Botswana. In: Hall, M., Avery, G., Avery, D.M., Wilson, M.L. \& Humphreys, A.J.B. (eds.), Frontiers: Southern African Archaeology Today. Cambridge Monographs in African Archaeology, BAR International Series 207. Cambridge, pp. 24-39.

Du Piesanie, J. 2008. Understanding the Socio-political Status of Leokwe Society During the Middle Iron Age in the Shashe-Limpopo Basin Through a Landscape Approach. Unpublished M.Sc. Thesis, University of the Witwatersrand, Johannesburg.

Forssman, T. 2013. A preliminary report on fieldwork in the Northern Tuli Game Reserve, northeastern Botswana. South African Archaeological Bulletin 68, 63-71.

Forssman, T. 2014. The Spaces Between Places: A Landscape Study of Foragers on the Greater Mapungubwe Landscape, Southern Africa. Unpublished Ph.D. Thesis, University of Oxford, Oxford.

Freeman-Greenville, G.S.P. 1962. The East African Coast: Select Documents from the First to the Earlier Nineteenth Century. Clarendon Press, Oxford.

Goren-Inbar, N., Lister, A., Werker, E. \& Chech, M. 1994. A butchered elephant skull and associated artifacts from the Acheulian site of Gesher Benot Ya'Aqov, Israel. Paléorient 20 (1), 99-112. http://dx.doi.org/10.3406/paleo.1994.4604

Graham, M.D., Douglas-Hamilton, I., Adams, W.M. \& Lee, P.C. 2009. The movement of African elephants in a human-dominated land-use mosaic. Animal Conservation 12 (5), 445-455. http://dx.doi.org/10.1111/j.1469-1795 $.2009 .00272 . x$

Gressier, C. 2012. An elephant in the room: Okavango safari hunting as ecotourism? Ethnos: Journal of Anthropology $10,1-22$.

Gröning, K. \& Saller, M. 1999. Elephants: A Cultural and Natural History. Konemann, Köln.

Grosse-Woodley, N. 2008. The Tsavo Trilogy. Severin Touristik, Sundern.

Hall, M. 1986. The role of cattle in southern African agropastoral societies: more than bones alone can tell. South African Archaeological Society Goodwin Series 5, 83-87.
Hall, S.L. \& Smith, B. 2000. Empowering places: rock shelters and ritual control in farmer-forager interactions in the Northern Province. South African Archaeological Society Goodwin Series 8, 30-46.

Hall-Martin, A.J. 1992. Distribution and status of the African elephant Loxodonta africana in South Africa, 1652-1992. Koedoe 35 (1), 65-88. http://dx.doi.org/10.4102/koedoe. v35i1.390

Hammond-Tooke, W.D. (ed.) 1974. The Bantu-speaking Peoples of Southern Africa. Routledge and Kegan Paul, London.

Hanisch, E.O.M. 1980. An Archaeological Interpretation of Certain Iron Age sites in the Limpopo / Shashe Valley. Unpublished M.Sc. Thesis, University of Pretoria, Pretoria.

Hanisch, E.O.M. 1981. The northern Transvaal: environment and archaeology. In: Voigt, E.A. (ed.), Guide to Archaeological Sites in the Northern and Eastern Transvaal. Transvaal Museum, Pretoria, pp. 1-6.

Haynes, G. \& Klimowicz, J. 2014. Recent elephant-carcass utilization as a basis for interpreting mammoth exploitation. Quaternary International (in press). http://dx.doi.org/10.1016/j. quaint.2013.12.040

Hoare, R.E. \& Du Toit, J.T. 1999. Coexistence between people and elephants in African savannas. Conservation Biology 13 (3), 633-639. http://dx.doi.org/10.1046/j.1523-1739 $.1999 .98035 . \mathrm{x}$

Howell, F.C. 1966. Observations on the earlier phases of the European Lower Palaeolithic. In: Clark, J.D. \& Howell, F.C. (eds.), Recent Studies in Palaeoanthropology. American Anthropologist 68 (2), pp. 88-201.

Huffman, T.N. 2000. Mapungubwe and the origins of the Zimbabwe culture. South African Archaeological Society Goodwin Series 8, 14-29.

Huffman, T.N. 2007. Handbook to the Iron Age: The Archaeology of Pre-colonial Farming Societies in Southern Africa. University of KwaZulu-Natal Press, Scottsville.

Huffman, T.N. 2008. Climate change during the Iron Age in the Shashe-Limpopo Basin, southern Africa. Journal of Archaeological Science 35 (7), 2032-2047. http://dx.doi. org/10.1016/j.jas.2008.01.005

Huffman, T.N. 2009. Mapungubwe and Great Zimbabwe: the origin and spread of social complexity in southern Africa. Journal of Anthropological Archaeology 28 (1), 37-54. http:// dx.doi.org/10.1016/j.jaa.2008.10.004

Huntingford, G.W.B. 1953a. The Northern Nilo-Hamites: Ethnographic Survey of Africa; East Central Africa, Part VI. African Institute, London.

Huntingford, G.W.B. 1953b. The Northern Nilo-Hamites: Ethnographic Survey of Africa; East Central Africa, Part VIII. African Institute, London.

Huntley, B.J. 1984. Characteristics of South African biomes. Ecological Studies 48, 1-17. http://dx.doi.org/10.1007/9783-642-69805-7_1 
Jackson, T.P., Mosojane, S., Ferreira, S. \& van Aarde, R.J. 2008. Solutions for elephant Loxodonta africana crop raiding in northern Botswana: moving away from symptomatic approaches. Oryx 42 (1), 83-91. http://dx.doi.org/10.1017/ S0030605308001117

Le Baron, J.C., Grab, S.W. \& Kuman, K. 2011. Surface texture analysis of southern Tuli Basin sediments: implications for Limpopo Valley geoarchaeological contexts. Journal of African Earth Sciences 59 (4-5), 384-394. http://dx.doi. org/10.1016/j.jafrearsci.2011.01.006

Loarie, S.R., van Aarde, R.J. \& Pimm, S.L. 2009a. Elephant seasonal vegetation preferences across dry and wet savannas. Biological Conservation 142 (12), 3099-3107. http:// dx.doi.org/10.1016/j.biocon.2009.08.021

Loarie, S.R., van Aarde, R.J. \& Pimm, S.L. 2009b. Fences and artificial water affect African savannah elephant movement patterns. Biological Conservation 142 (12), 3086-3098. http:// dx.doi.org/10.1016/j.biocon.2009.08.008

Luxmoore, R. 1991. The ivory trade. In: Eltringham, S.K. (ed.), The Illustrated Encyclopedia of Elephants. Salamander, London, pp. 148-157.

Manyanga, M. 2006. Resilient Landscapes: Socio-environmental Dynamics in the Shashi-Limpopo Basin, Southern Zimbabwe c. AD 800 to the Present. Unpublished Ph.D. Thesis, Uppsala University, Uppsala.

Manyanga, M., Pikirayi, I. \& Ndoro, W. 2000. Coping with dryland environments: preliminary results from Mapungubwe and Zimbabwe phase sites in the Mateke Hills, south-eastern Zimbabwe. South African Archaeological Society Goodwin Series 8, 69-77.

Marks, S.A. 1973. Prey selection and annual harvest of game in a rural Zambian community. African Journal of Ecology 11 (2), 113-128. http://dx.doi.org/10.1111/j.1365-2028.1973. tb00077.x

Marks, S.A. 1977. Hunting behavior and strategies of the Valley Bisa in Zambia. Human Ecology 5 (1), 1-36. http://dx.doi. org/10.1007/BF01880256

Mbaiwa, J.E. \& Mbaiwa, O.I. 2006. The effects of veterinary fences on wildlife populations in Okavango Delta, Botswana. International Journal of Wilderness 13, 17-41.

Meredith, M. 2001. Elephant Destiny: Biography of an Endangered Species in Africa. Public Affairs, New York.

Milner-Gulland, E.J. \& Beddington, J.R. 1993. The exploitation of elephants for the ivory trade: an historical perspective. Biological Sciences 252 (1333), 29-37. http://dx.doi.org/10.1098/ rspb.1993.0042

Mitchell, P.J. 2005. African Connections: Archaeological Perspectives on Africa and the Wider World. AltaMira Press, Walnut Creek.

Moss, C.J. 2001. The demography of an African elephant (Loxodonta africana) population in Amboseli, Kenya. Journal of Zoology 255 (2), 145-156. http://dx.doi.org/10.1017/ S0952836901001212
Movius, H.L. 1950. A wooden spear of Third Interglacial age from Lower Saxony. South-western Journal of Anthropology $6,139-142$.

Mucina, L. \& Rutherford, M.C. (eds.) 2006. The Vegetation of South Africa, Lesotho and Swaziland. South African National Biodiversity Institute, Pretoria.

Noli, D. \& Avery, G. 1988. Protein poisoning and coastal subsistence. Journal of Archaeological Science 15 (4), 395-401. http://dx.doi.org/10.1016/0305-4403(88)90037-4

Ntumi, C.P., Ferreira, S.M. \& van Aarde, R.J. 2009. A review of historical trends in the distribution and abundance of elephants Loxodonta africana in Mozambique. Oryx 43 (4), 568-579. http://dx.doi.org/10.1017/S0030605309990482

Nyhus, P.J., Tilson, R. \& Sumianto 2008. Crop-raiding elephants and conservation implications at Way Kambas National Park, Sumatra, Indonesia. Oryx 34 (4), 262-274. http://dx.doi. org/10.1017/S0030605300031331

Parker, I.S.C. \& Martin, E.B. 1982. How many elephants are killed for the ivory trade? Oryx 16 (3), 235-239. http://dx.doi. org/10.1017/S0030605300017452

Plug, I. 1989. Aspects of life in the Kruger National Park during the Early Iron Age. South African Archaeological Society Goodwin Series 6, 62-68.

Plug, I. 2000. Overview of Iron Age fauna from the Limpopo Valley. South African Archaeological Society Goodwin Series 8, 117-126.

Plug, I. \& Badenhorst, S. 2001. The Distribution of Macromammals in Southern Africa over the Past 30000 Years as Reflected in Animal Remains from Archaeological Sites. Transvaal Museum Monograph 12. Transvaal Museum, Pretoria.

Plug, I. \& Badenhorst, S. 2006. Notes on the fauna from three Late Iron Age mega-sites, Boitsemagano, Molokwane and Mabjanamatshwana, North West Province, South Africa. South African Archaeological Bulletin 61, 57-67.

Plug, I., Scott, K. \& Fish, W. 2000. Schoemansdal: faunal remains from selected sites in an historical village. Annals of the Transvaal Museum 37, 125-130.

Prins, H.H.T. 1992. The pastoral road to extinction: competition between wildlife and traditional pastoralism in East Africa. Environmental Conservation 19 (2), 117-123. http://dx.doi. org/10.1017/S0376892900030587

Roodt, V. 1998. Trees and Shrubs of the Okavango Delta: Medicinal Uses and Nutritional Value. Shell Oil Botswana, Gaborone.

Scholes, R.J. \& Mennell, K. 2008. Elephant Management: A Scientific Assessment for South Africa. Wits University Press, Johannesburg.

Scoones, I. 1991. Wetlands in drylands: key resources for agricultural and pastoral production in Africa. Ambio 20, 366-371.

Selier, S.A.J. 2007. The social structure, distribution and demographic status of the African elephant population in the Central Limpopo River Valley of Botswana, Zimbabwe and South Africa. Center for Wildlife Management, University of Pretoria, Pretoria. 
Selier, S.A.J., Page, B.R., Vanak, A. \& Slotow, R. 2014. Sustainability of elephant hunting across international borders in southern Africa: a case study of the Greater Mapungubwe Transfrontier Conservation Area. Journal of Wildlife Management 78 (1), 122-132. http://dx.doi.org/10.1002/ jwmg.641

Selous, F.C. 1881. A Hunter's Wanderings in Africa. R. Bentley \& Son, London.

Shannon, G., Matthews, W.S., Page, B.R., Parker, G.E. \& Smith, R.J. 2009. The affects of artificial water availability on large herbivore ranging patterns in savanna habitats: a new approach based on modelling elephant path distributions. Diversity and Distributions 15 (5), 776-783. http://dx.doi. org/10.1111/j.1472-4642.2009.00581.x

Sinclair, P. 1982. Chibuene: an early trading site in southern Mozambique. Paideuma 28, 150-164.

Sinclair, P., Ekblom, A. \& Wood, M. 2012. Trade and society on the south-east African coast in the later first millennium AD: the case of Chibuene. Antiquity 86, 723-737.

Skead, C.J., Boshoff, A., Kerley, G.I.H. \& Lloyd, P. 2007. Historical Incidence of the Larger Land Mammals in the Broader Eastern Cape. Centre for African Conservation Ecology, Nelson Mandela Metropolitan University, Port Elizabeth.

Skinner, J. \& Smithers, R. 1990. The Mammals of Southern African Subregion (2nd edition). University of Pretoria, Pretoria.

Smith, J. 2005. Climate Change and Agropastoral Sustainability in the Shashe-Limpopo River Basin from AD 900. Unpublished Ph.D. Thesis, University of the Witwatersrand, Johannesburg.

Smith, J., Lee-Thorp, J. \& Hall, S. 2007. Climate change and agropastoralist settlement in the Shashe-Limpopo River Basin, southern Africa: AD 880 to 1700. South African Archaeological Bulletin 62, 115-125.

Spinage, C.A. 1973. A review of ivory exploitation and elephant population trends in Africa. African Journal of Ecology 11 (3-4), 281-289. http://dx.doi.org/10.1111/j.1365-2028.1973. tb00093.x

Steenkamp, G., Ferreira, S.M. \& Bester, M.N. 2007. Tusklessness and tusk fractures in free-ranging African savanna elephants (Loxodonta africana). Journal of the South African Veterinary Association 78 (2), 75-80. http://dx.doi.org/10.4102/jsava. v78i2.294

Stiles, D. 2004. The ivory trade and elephant conservation. Environmental Conservation 31 (4), 309-321. http://dx.doi. org/10.1017/S0376892904001614

Theal, G.M. 1901. Records of South-Eastern Africa Collected in Various Libraries and Archive Departments in Europe. Struik, Cape Town.

Turner, G. 1987. Early Iron Age herders in northwestern Botswana: the faunal evidence. Botswana Notes and Records 19, 7-23.
Tyson, P.D. \& Lindesay, J.A. 1992. The climate of the last 2000 years in southern Africa. The Holocene 2 (3), 271-278. http:// dx.doi.org/10.1177/095968369200200310

van Aarde, R.J., Ferreira, S.M., Jackson, T., Page, B., De Beer, Y., Gough, K., Guldemond, R., Junker, J., Olivier, P., Ott, T. \& Trimble, M. 2008. Elephant population biology and ecology. In: Scholes, R.J. \& Mennell, K.G. (eds.), Elephant Management: A Scientific Assessment for South Africa. Wits University Press, Johannesburg, pp. 84-145.

van Aarde, R.J., Jackson, T. \& Erasmus, D.G. 2005. Assessment of Seasonal Homerange use by Elephants Across Southern Africa's Seven Elephant Clusters. Unpublished Report. Conservation Ecology Research Unit, Peace Parks Foundation, University of Pretoria, Pretoria. Available on http://www. up.ac.za/academic/zoology/ceru/Home.htm.

van Doornum, B.L. 2008. Sheltered from change: hunter-gatherer occupation of Balerno Main Shelter, Shashe-Limpopo confluence area, South Africa. Southern African Humanities 20, 249-284.

van Wyk, B. \& van Wyk, P. 2007. Field Guide to Trees of Southern Africa. Struik, Cape Town.

van Wyk, B., van Wyk, P. \& van Wyk, B.E. 2008. Photo Guide to Trees of Southern Africa. Briza, Pretoria.

Villa, P. 1990. Torralba and Aridos: elephant exploitation in Middle Pleistocene Spain. Journal of Human Evolution 19 (3), 299-309. http://dx.doi.org/10.1016/0047-2484(90)90071-I

Voigt, E.A. 1981. The faunal remains from Schroda. In: Voigt, E.A. (ed.), A Guide to Archaeological Sites in the Northern and Eastern Transvaal. Transvaal Museum, Pretoria, pp. 55-60.

Voigt, E.A. \& Plug, I. 1981. Early Iron Age Herders of the Limpopo Valley. Transvaal Museum, Pretoria.

Ward, R. 1992. Records of Big Game: The Centenary Edition, 1892-1992. Roland Ward Publications, San Antonio.

Wenban-Smith, F.F., Allen, P., Bates, M.R., Parfitt, S.A., Preece, R.C., Stewart, J.R., Turner, C. \& Whittaker, J.E. 2006. The Clactonian elephant butchery site at Southfleet Road, Ebbsfleet, UK. Journal of Quaternary Science 21 (5), 471-483. http://dx.doi.org/10.1002/jqs.1033

Wood, M. 2000. Making connections: relationships between international trade and glass beads from the Shashe-Limpopo area. South African Archaeological Society Goodwin Series $8,78-90$.

Wood, M. 2005. Glass Beads and Pre-European Trade in the Shashe-Limpopo Region. Unpublished M.Sc. Thesis, University of the Witwatersrand, Johannesburg.

Yravedra, J., Domínguez-Rodrigo, M., Santonja, M., PérezGonzález, A., Panera, J., Rubio-Jara, S. \& Baquedano, E. 2010. Cut marks on the Middle Pleistocene elephant carcass of Aridos 2 (Madrid, Spain). Journal of Archaeological Science 37 (10), 2469-2476. http://dx.doi.org/10.1016/j.jas.2010.05.007 